\title{
The angiotensin-converting enzyme 2 (ACE2) receptor in the prevention and treatment of COVID-19 are distinctly different paradigms
}

\author{
Craig Steven McLachlan®
}

\begin{abstract}
There is current debate concerning the use of angiotensin-converting enzyme (ACE) inhibitors or angiotensin II type 1 receptor blockers (ARBs), for hypertension management, during COVID-19 infection. Specifically, the suggestion has been made that ACE inhibitors or ARBs could theoretically contribute to infection via increasing ACE2 receptor expression and hence increase viral load. The ACE2 receptor is responsible for binding the SAR-CoV2 viral spike and causing COVID-19 infection. What makes the argument somewhat obtuse for ACE inhibitors or ARBs is that ACE2 receptor expression can be increased by compounds that activate or increase the expression of SIRT1. Henceforth common dietary interventions, vitamins and nutrients may directly or indirectly influence the cellular expression of the ACE2 receptor. There are many common compounds that can increase the expression of the ACE2 receptor including Vitamin C, Metformin, Resveratrol, Vitamin B3 and Vitamin D. It is important to acknowledge that down-regulation or blocking the cellular ACE2 receptor will likely be pro-inflammatory and may contribute to end organ pathology and mortality in COVID-19. In conclusion from the perspective of the ACE2 receptor, COVID-19 prevention and treatment are distinctly different. This letter reflects on this current debate and suggests angiotensin-converting enzyme inhibitors and ARBs are likely beneficial during COVID-19 infection for hypertensive and normotensive patients.
\end{abstract}

Keywords: ACE2 receptor, COVID-19, SIRT1, ACE inhibitors, ARBs, Vitamin C, Metformin, Resveratrol, Coronavirus, SAR-COV2

\section{Main text}

The angiotensin-converting enzyme 2 (ACE2) receptor acts as the receptor-binding domain for the SAR-CoV2 virus spike complex [1]. This permits viral attachment, fusion and intracellular entry and infection with COVID-19 [1]. Compounds that may increase the expression of the ACE2 receptor have received media interest [2]. Particularly, from the point of view, that increased expression of the ACE2 receptor, may make

Correspondence: reperfusion@hotmail.com

Torrens University Australia, Health Vertical, 5/235 Pyrmont St, Pyrmont, NSW 2009, Australia
SAR-CoV2 more infective via increasing viral load, morbidity and mortality [2-4]. From the perspective of the ACE2 receptor, COVID-19 prevention and treatment are distinctly different.

COVID-19 prevention via targeting the cellular ACE2 receptor is theoretically interesting, it is however, not a practically useful strategy and could potentially increase mortality $[2,3]$. On the other hand, there has been interest in delivering soluble ACE2 receptors that may bind SAR-CoV2 spikes and deactivate the virus. This would be a practical solution, as this leaves the cellular ACE2 receptor system intact (if all virus is bound to decoy

C C The Author(s). 2020 Open Access This article is licensed under a Creative Commons Attribution 4.0 International License, which permits use, sharing, adaptation, distribution and reproduction in any medium or format, as long as you give appropriate credit to the original author(s) and the source, provide a link to the Creative Commons licence, and indicate if changes were made. The images or other third party material in this article are included in the article's Creative Commons licence, unless indicated otherwise in a credit line to the material. If material is not included in the article's Creative Commons licence and your intended use is not permitted by statutory regulation or exceeds the permitted use, you will need to obtain permission directly from the copyright holder. To view a copy of this licence, visit http://creativecommons.org/licenses/by/4.0/. The Creative Commons Public Domain Dedication waiver (http://creativecommons.org/publicdomain/zero/1.0/) applies to the data made available in this article, unless otherwise stated in a credit line to the data. 
soluble ACE2 receptors) [5]. Soluble ACE2 receptors can reduce vial load up to 5000-fold (in cell culture) and be used to reduce viral load early or as a treatment option to preserve lung during acute and severe respiratory involvement [6].

Some investigator groups have suggested that ACE inhibitors may be a logical choice for all patients with COVID-19 infection [7]. This is irrespective if patients have pre-existing hypertension or not. The rationale for giving $\mathrm{ACE}$ inhibitors to all patients is that it may enhance the expression of ACE2 receptors that further reduce cellular inflammation [2, 7]. There is limited evidence that ACE inhibitors or angiotensin II type 1 receptor blockers (ARB's) may up-regulate ACE2 receptor mRNA and or expression [2].

Importantly, the COVID-19 infection effectively downregulates the ACE2 receptor via attaching to infectionrelated transcription factors at the ACE2 regulatory regions [2]. ANG II also reduces the expression of the ACE2 receptor. Cardiac, lung, liver and renal damage is responsible for morbidity and mortality in COVID-19 [8]. These organ systems have a higher expression of ACE2 receptors than other bodily systems. Because ACE2 converts Ang II to Ang [1-7], down-regulation of the ACE2 receptor would leave critical organ systems susceptible to hyper-inflammation via unopposed increases in Angiotensin II (ANG II) [2]. Respiratory distress in COVID-19 and SARS is likely associated with reduced ACE2 receptor expression [2, 7-9]. Individuals with diabetes, high blood pressure, metabolic syndrome and advanced age (with reduced organ ACE2 expression) are prone to higher fatality rates [10].

There has also been significant media discussion around blood pressure management in COVID-19 [2]. Blood pressure therapeutics that target the angiotensin system have been discussed at length in journal editorial articles. Professional societies have now released position statements stating that ACE inhibitors and ARBs should not be withdrawn either as a preventive measure or as a treatment option in COVID-19 [2]. Angiotensin II formation would prevail if ACE inhibitors or ARBs as a mono-class are withdrawn in hypertensive patients [2, 4]. In hypertension ACE inhibitors are serving to restore the balance of ACE2 to ANG II formation. It is possible that ACE inhibitors may reduce the down regulation of ACE2 receptors via reducing ANG II formation in COVID-19 [2, 7, 9].

Interestingly, it is not only $\mathrm{ACE}$ inhibitors and ARBs at therapeutic doses that can influence ACE2 expression. There are other mediators that may increase the expression of ACE2 such as increased potassium intake [11], intermittent fasting [12], nicotine [13] and Vitamin D [14].

It is important to consider that ACE2 expression can be increased by compounds that activate or increase the expression of SIRT1 $[15,16]$. SIRT1 is expressed next to the promotor region of ACE2 gene hence increased expression and or enhanced functional activation of SIRT1 is associated with an increase in expression of ACE2 [16]. Common mediators that interact positively with SIRT1 expression or activation (directly or indirectly) are calorie restriction [17], resveratrol [18, 19], Vitamin $C$ [20, 21], aspirin [20], metformin [22], vitamin B3 [23]. This may provide a mechanistic explanation as to why high dose Vitamin $C$ is a potential rescue therapy for severe acute respiratory distress syndrome in COVID-19 [10].

Key points with respect to COVID-19 respiratory infection

- Down-regulation or blocking the cellular ACE2 receptor will be pro-inflammatory and may contribute to end organ pathology.

- Therapeutics that stimulate the functional expression of ACE2 receptor or inhibit ACE II could be a useful therapeutic approach.

- ACE inhibitors or ARBs may be safe in both hypertensive and normotensive patients

- Editorial discussion whether ACE inhibitors or ARBs should be discontinued or continued with respect to ACE2 expression, seems obtuse. Particularly when other therapeutics, dietary interventions, vitamins and nutrients may directly or indirectly may influence the cellular expression of the ACE2 receptor.

- There are many common compounds that can increase the expression of the ACE2 receptor including Vitamin C, Metformin, Resveratrol, Vitamin B3 and Vitamin D.

\section{Abbreviations}

ANG II: Angiotensin II; ACE2: Angiotensin-converting enzyme 2;

ARB's: Angiotensin II type 1 receptor blockers; mRNA: Messenger RNA; SARSCoV-2: Severe acute respiratory syndrome coronavirus 2; SARS: Severe acute respiratory syndrome; SIRT1: Sirtuin 1

Acknowledgements

Not applicable.

Author's contributions

Craig S McLachlan contributed solely to the ideas and write up of the letter. The author(s) read and approved the final manuscript.

Funding

Not applicable.

Availability of data and materials

Not applicable.

Ethics approval and consent to participate Not applicable.

Consent for publication

Not applicable.

Competing interests

Not applicable. 
Received: 16 April 2020 Accepted: 1 June 2020

Published online: 15 July 2020

\section{References}

1. Cao Y, Li L, Feng Z, et al. Comparative genetic analysis of the novel coronavirus (2019-nCoV/SARS-CoV-2) receptor ACE2 in different populations. Cell Discov. 2020;6:11.

2. Vaduganathan M, Vardeny O, Michel T, McMurray JJV, Pfeffer MA, Solomon SD. Renin-angiotensin-aldosterone system inhibitors in patients with Covid19. N Engl J Med. 2020. https://doi.org/10.1056/NEJMsr2005760.

3. Chen J, Jiang Q, Xia X, Liu K, Yu Z, Tao W, Gong W, Han JJ. Individual variation of the SARS-CoV2 receptor ACE2 gene expression and regulation; 2020. p. 2020030191

4. Sommerstein R, Kochen MM, Messerli FH, Gräni C. Coronavirus disease 2019 (COVID-19): do angiotensin-converting enzyme inhibitors/angiotensin receptor blockers have a biphasic effect? J Am Heart Assoc. 2020;9(7): e016509. https://doi.org/10.1161/JAHA.120.016509.

5. Zhang H, Penninger JM, Li Y, Zhong N, Slutsky AS. Angiotensin-converting enzyme 2 (ACE2) as a SARS-CoV-2 receptor: molecular mechanisms and potential therapeutic target. Intensive Care Med. 2020;46(4):586-90. https:// doi.org/10.1007/s00134-020-05985-9.

6. Monteil V, Kwon H, Prado P, Hagelkrüys A, Wimmer RA, Stahl M, Leopoldi A Garreta E, del Pozo CH, Prosper F, Romero JP, Wirnsberger G, Zhang H, Slutsky AS, Conder R, Montserrat N, Mirazimi A, Penninger JM. Inhibition of SARS-CoV-2 infections in engineered human tissues using clinical-grade soluble human ACE2. 2020;181:905-913.e7. https://doi.org/10.1016/j.cell. 2020.04.004

7. Sun ML, Yang JM, Sun YP, Su GH. Inhibitors of RAS might be a good choice for the therapy of COVID-19 pneumonia. Zhonghua Jie He He Hu Xi Za Zhi. 2020:43(3):219-22. https://doi.org/10.3760/cma.j.issn.1001-0939.2020.03.016.

8. Cheng H, Wang Y, Wang GQ. Organ-protective effect of angiotensinconverting enzyme 2 and its effect on the prognosis of COVID-19. J Med Virol. 2020. https://doi.org/10.1002/jmv.25785.

9. Glowacka I, Bertram S, Herzog P, Pfefferle S, Steffen I, Muench MO, Simmons G, Hofmann H, Kuri T, Weber F, Eichler J, Drosten C, Pöhlmann S. Differential downregulation of ACE2 by the spike proteins of severe acute respiratory syndrome coronavirus and human coronavirus NL63. J Virol. 2010;84(2): 1198-205. https://doi.org/10.1128/JVI.01248-09 Epub 2009;28.

10. Fang $\mathrm{L}$, Karakiulakis $\mathrm{G}$, Roth $\mathrm{M}$. Are patients with hypertension and diabetes mellitus at increased risk for COVID-19 infection? Lancet Respir Med. 2020; 8(4):e21. https://doi.org/10.1016/S2213-2600(20)30116-8.

11. Gonzalez AA, Gallardo M, Cespedes C, Vio CP. Potassium intakes prevents the induction of the Renin Angiotensin System and increases medullary ACE1 and COX-2 in the kidneys of Angiotensin II dependent hypertensive rats. Front Pharmacol. 2019;10:1212.

12. Badreh F, Joukar S, Badavi M, Rashno M. Restoration of the reninangiotensin system balance is a part of the effect of fasting on cardiovascular rejuvenation: role of age and fasting models. Rejuvenation Res. 2019. https://doi.org/10.1089/rej.2019.2254

13. Olds JL, Kabbani N. Is nicotine exposure linked to cardiopulmonary vulnerability to COVID-19 in the general population? FEBS J. 2020. https:// doi.org/10.1111/febs.15303.

14. Xu J, Yang J, Chen J, Luo Q, Zhang Q, Zhang H. Vitamin D alleviates lipopolysaccharide-induced acute lung injury via regulation of the reninangiotensin system. Mol Med Rep. 2017;16(5):7432-8.

15. Clarke NE, Belyaev ND, Lambert DW. Turner AJ epigenetic regulation of angiotensin-converting enzyme 2 (ACE2) by SIRT1 under conditions of cell energy stress. Clin Sci (Lond). 2014;126(7):507-16.

16. Patel VB, Zhong JC, Grant MB, Oudit GY. Role of the ACE2/Angiotensin 1-7 axis of the renin-angiotensin system in heart failure. Circ Res. 2016;118(8): $1313-26$.

17. Yu W, Qin J, Chen C, Fu Y, Wang W. Moderate calorie restriction attenuates age-associated alterations and improves cardiac function by increasing SIRT1 and SIRT3 expression. Mol Med Rep. 2018;18(4):4087-94.

18. Kim EN, Kim MY, Lim JH, Kim Y, Shin SJ, Park CW, Kim YS, Chang YS, Yoon HE, Choi BS. The protective effect of resveratrol on vascular aging by modulation of the renin-angiotensin system. Atherosclerosis. 2018; 270:123-31

19. Borra MT, Smith BC, Denu JM. Mechanism of human SIRT1 activation by resveratrol. J Biol Chem. 2005;280(17):17187-95.
20. Aşcı H, Saygın M, Yeşilot \$̧, Topsakal \$̧, Cankara FN, Özmen Ö, Savran M. Protective effects of aspirin and vitamin $\mathrm{C}$ against corn syrup consumptioninduced cardiac damage through sirtuin-1 and HIF-1a pathway. Anatol J Cardiol. 2016;16(9):648-54.

21. Qi MZ, Yao Y, Xie RL, Sun SL, Sun WW, Wang JL, Chen Y, Zhao B, Chen EZ, Mao EQ. Intravenous Vitamin C attenuates hemorrhagic shock-related renal injury through the induction of SIRT1 in rats. Biochem Biophys Res Commun. 2018;501(2):358-64.

22. Cuyàs $E$, Verdura $S$, Llorach-Parés L, Fernández-Arroyo S, Joven J, MartinCastillo B, Bosch-Barrera J, Brunet J, Nonell-Canals A, Sanchez-Martinez M, Menendez JA. Metformin is a direct SIRT1-activating compound: computational modeling and experimental validation. Front Endocrinol. 2018;9:657.

23. Hong G, Zheng D, Zhang L, Ni R, Wang G, Fan GC, Lu Z, Peng T. Administration of nicotinamide riboside prevents oxidative stress and organ injury in sepsis. Free Radic Biol Med. 2018;123:125-37.

\section{Publisher's Note}

Springer Nature remains neutral with regard to jurisdictional claims in published maps and institutional affiliations.
Ready to submit your research? Choose BMC and benefit from:

- fast, convenient online submission

- thorough peer review by experienced researchers in your field

- rapid publication on acceptance

- support for research data, including large and complex data types

- gold Open Access which fosters wider collaboration and increased citations

- maximum visibility for your research: over $100 \mathrm{M}$ website views per year

At $\mathrm{BMC}$, research is always in progress.

Learn more biomedcentral.com/submissions 